This is a pre-copyedited, author-produced version of an article accepted for publication in Social History of Medicine following peer review. The version of record, "David R Green, Douglas H L Brown, Kathleen McIlvenna, Addressing Ill Health: Sickness and Retirement in the Victorian Post Office, Social History of Medicine, Volume 33, Issue 2, May 2020, Pages 559-585", is available online at: https://doi.org/10.1093/shm/hky081 


\section{Addressing ill health: Sickness and retirement in the Victorian Post Office.}

\section{Introduction}

The growth of the service sector was one of the main changes in the development of the nineteenthcentury British economy and yet we know hardly anything about the occupational health of its workforce. Accidents and occupational diseases such as arsenic and lead poisoning, asbestosis, anthrax or phosphorus necrosis were far more newsworthy than the seemingly innocuous health problems that affected service sectors workers which, in comparison, were 'unspectacular and insidious' ${ }^{1}$ As a result, compared to manufacturing, mining and other dangerous trades, health

We are extremely grateful to the Postal Museum archives for permission to use the pensions data for this article and to Chris Taft and his colleagues for their knowledgeable advice on the records. We would also like to thank Oliver Carter-Wakefield for some preliminary work on gathering the data, Martin Gorsky for his advice on questions about occupational health, and Dr Hilary Guite for help in understanding the epidemiology of diseases. We would also like to thank the three anonymous referees for helpful comments on an earlier draft of this paper. Kingston University and King's College London generously provided funding that has enabled this research to take place.

\footnotetext{
${ }^{1}$ There is an extensive literature on the dangerous trades. See Bartrip, P. W. J., The Home Office and the Dangerous Trades: regulating occupational disease in Victorian and Edwardian Britain (Amseterdam: Rodophi, 2002), 283. For the match makers see Barbara Harrison, 'The politics of occupational ill-health in late nineteenth century Britain: the case of the match making industry', Sociology of Health \& IIIness, 1995, 17, 2041; Louise Raw, Striking a Light: The Bryant and May Matchwomen and their Place in History (London: Bloomsbury, 2011). For recent publications on mining and occupational health see A. Mclvor and R. Johnston, Miners' Lung: A History of Dust Disease in British Coal Mining (London: Routledge, 2007); C. Mills, Regulating Health and Safety in the British Mining Industries, 1800-1914 (Farnham: Ashgate, 2010); C. Mills and W P Adderley, 'Occupational exposure to heavy metals poisoning: Scottish lead mining', Social History of Medicine 30 (2017), 53-543; D. Selway, 'Death Underground: Mining Accidents and Memory in South Wales, 1913-74', Labour History Review, 2016, 81 187-209. For occupational health more generally see P. Weindling (ed.) The Social History of Occupational Health (1985).
} 
risks in service sector employments passed relatively unnoticed, both by the medical profession and society as a whole. ${ }^{2}$

The Post Office was one of the most important institutions in the development of the modern British state, employing thousands of people across the country and delivering an ever growing volume of mail and, from 1870, an increasing number of telegrams. The workforce grew from around 22,000 permanent or 'established' employees in the mid-1850s to over 88,000 by the end of the century, with many more non-established workers employed on part time or temporary contracts. ${ }^{3}$ Serving in the Post Office, required not just an impeccable character and the ability to read, but also good health. Maintaining a fit and healthy workforce capable of sorting and delivering the huge quantity of mail and messages in a timely and efficient way was the foundation upon which the whole system relied and the Post Office developed ways of monitoring and addressing sickness far in advance of other sectors of the economy. Ensuring workers' health, from the point of recruitment to the granting of a pension, was the responsibility of the Post Office medical service which was therefore as crucial to the efficient running of the system as were the trains and telegraph by which letters and messages were conveyed. ${ }^{4}$

\footnotetext{
${ }^{2}$ For a useful review of the historiography of occupational illness see P. Weindling (ed), The Social History of Occupational Health (London: Croom Helm, 1985). For a more recent historiography see Bartrip, P. W. J., The Home Office and the Dangerous Trades, 29-34. See also J. Melling, 'Employers, Industrial Welfare and the Struggle for Work-Place Control in British Industry, 1880-1920' in H. F. Gospel and C. R. Littler (eds.) Managerial Strategies and Industrial Relations: An Historical and Comparative Study (Farnham: Ashgate, 1983), 55-81; J Melling, 'Welfare Capitalism and the Origins of Welfare States: British Industry, Workplace Welfare and Social Reform, c. 1870-1914', Social History, 1992, 17, 453-478. For children and health see P. Kirby, Child Workers and Industrial Health in Britain, 1780-1850 (Woodbridge, Suffolk: Boydell Press/ Economic History Society, 2013). For women in white collar work see Barbara Harrison, Not Only the Dangerous Trades: Women's Work and Health In Britain 1880-1914 (London: Taylor and Francis, 1996), 111-142.

${ }^{3}$ Figures for established employees come from 1854-5 [Cd.1913] First report of the Postmaster General on the Post Office, 20; 1899 (Cd. 9463] Forty-fifth report of the Postmaster General on the Post Office, 43. These figures do not include part time or unestablished employees who were not entitled to a pension.

${ }^{4}$ For a discussion of the Post Office medical service see Mcllvenna, K, Brown, D and Green, D. R., 'Medicine and modernity: creating the Victorian Post Office medical service', forthcoming.
} 
Up until the 1890s, at which point annual reports of the Chief Medical Officer began to be published, the Post Office kept its health statistics 'shrouded in mystery'. ${ }^{5} \mathrm{Dr}$ J. T. Arlidge, who wrote the definitive text on occupational health in 1892 , found it impossible to extract details and relied on snippets of evidence passed to him by a friend. However, information about sickness in the Post Office workforce was included in the pension records for eligible workers and these provide us with a unique opportunity to explore patterns of ill health in the workforce. ${ }^{6}$ Although the health risks faced by postal workers were far less newsworthy than the accidents or the disabling and disfiguring industrial diseases suffered by many workers in manufacturing and mining, there were still specific risks attached to the kinds of work undertaken by the growing army of clerks, messengers, postmen, sorters, stampers, and telegraphists employed in the Victorian Post Office. Different working environments, different kinds of work and groups of workers, and different types of locations each played a part in influencing the pattern of sickness, as did the effect of living in overcrowded and insanitary conditions in towns and cities. In this research we describe and explain the nature of ill health and sickness absence in this important branch of the Victorian economy. We draw attention to the relationships between workplace, living conditions and ill health in relation to ill health. We address three main sets of questions: (i) how important was ill health in relation to retirement; (ii) what kinds of complaints resulted in workers being pensioned off and how did this vary over time; and (iii) what factors influenced the incidence and prevalence of ill health, including age, gender, occupation and place of work? Using evidence provided by Post Office doctors that was included in the pensions records, we compare and explain differing health outcomes within the workforce, taking into account the impact and inter-relationships of social, occupational and environmental factors on the prevalence of sickness and the incidence of disease.

\footnotetext{
5 J. T. Arlidge, The Hygiene, Diseases and Mortality of Occupations (London: Percival, 1892), 94.

${ }^{6}$ For the relationship between the Post Office and the state see Patrick Joyce, The State of Freedom (Cambridge: Cambridge University Press, 2013), 53-186.
} 


\section{Pensions and Medical Provision in the Post Office}

The introduction of medical services in the Civil Service, including the Post Office, from mid-century was largely the product of the widespread introduction of pensions, though it took time for the system to develop full coverage of the workforce in different government departments. From 1859, under the Superannuation Act, civil servants, including Post Office workers, who had been employed for ten years or more became eligible for a pension, either upon reaching the age of 60 or on grounds of ill health. ${ }^{7}$ It became even more important, therefore, that applicants for a job in the Post Office were deemed fit enough to work, and as a result the need to appoint medical officers to ensure this examination was carried out rigorously emerged. The first medical officer to the Post Office, Dr Waller Lewis, was appointed in 1855 to oversee the health of the London workforce and in the same year medical officers were also appointed in Edinburgh, Glasgow, Dublin and Liverpool, either paid an annual salary or a capitation fee of $8 s 6 d$ per employee. ${ }^{8}$ Appointments followed shortly in other large provincial cities, including Birmingham, Bristol, Leeds and Manchester. ${ }^{9}$ In smaller places permanent appointments were delayed and a capitation fee paid to doctors contracted to provide care for the workforce. From the 1870s the medical service expanded considerably, matching the growing volume of work and number of employees in the most rapidly expanding towns and cities. By 1870, in addition to those in London, medical officers were employed in at least 30 large towns and cities and by the end of the century there were over 570 medical officers employed either permanently or on a contract basis by the Post Office. By then Dr Waller Lewis had been appointed as the Chief Medical Officer to oversee the entire system, assisted by a

\footnotetext{
${ }^{7}$ Some employees from London, Dublin and Edinburgh were eligible for pensions from 1829. This was noncontributory for letter-carriers but others had to pay towards this pension. The numbers, however, were small. See Post Office Archives POST 66/12, Report from Commissioners on the operation of the Superannuation Act, 20-22.

8 POST 121/578/3, FILE 3, Provincial Medical Officers: general duties.

${ }^{9}$ Post Office Archives, POST 64/1, The Post Office Medical System, 15, 22, 28-29, 71.
} 
deputy and in 1882 by the first female medical officer who was employed to look after the large and growing number of female employees in the General Post Office in London. ${ }^{10}$

Doctors working for the Post Office were responsible for assessing candidates for jobs and ensuring that only those who passed a medical examination demonstrating fitness and strength were taken on. In London and Dublin, for example, in the mid-1850s, one in four applicants as letter carriers were rejected on grounds of poor health and physique and the proportion was said to be even higher in Edinburgh. ${ }^{11}$ From the 1870s, at the end of a six month probation - later extended to two years - further medical examinations were required and failure to maintain good health usually resulted in dismissal. ${ }^{12}$ Once employed, however, a growing number of postal workers were able to benefit from free medical care, the provision of relatively generous amounts of sick pay and, from 1859 , the ability to retire with a pension upon reaching the age of sixty or, more commonly in the Post Office, on grounds of ill health certified by the Post Office doctor. In order to combat malingering, medical officers were required to record bona fide absence on grounds of ill health and to keep a journal of sick absences. ${ }^{13}$ Workers who were likely to be absent for over a year (later extended to three years) on grounds of ill health were liable to be pensioned off, and therefore it was important to note down the length of sickness related absences as well as any causes that would incapacitate a worker from undertaking their role. Recording and collating these details was an important task for Post Office doctors and crucial for the entire system of pension provision.

The pensions records used in this research provide a new source of evidence with which to explore patterns of morbidity in nineteenth-century Britain. They shed light on the health outcomes for

\footnotetext{
${ }^{10} 1899$ [C.9463] Forty-fifth report of the Postmaster General on the Post Office, 17; 1883 [C.3703] Twentyninth report of the Postmaster General on the Post Office, 3. See also POST 64/1, 155-59. For further discussion see Mcllvenna, K, Brown, D and Green, D. R., 'Medicine and modernity: creating the Victorian Post Office medical service', forthcoming.

${ }^{11} 1856$ [Cd. 2048] Second report of the Postmaster General on the Post Office, 29.

12 POST 64/1, The Post Office Medical System, 191.

${ }^{13}$ See POST 64/7 General Instructions issued to Medical Officers, December 1880.
} 
workers who had served at least ten years in the Post Office and were eligible for a pension. ${ }^{14}$ As well as information on age, gender and occupation, the records also contain details of the place of employment, length of service, the number of days off for sickness and for other causes in the preceding ten years and the reason for being pensioned off, including brief details of medical complaints leading to incapacity.

Identifying and explaining patterns of morbidity, however, as other scholars have noted, is exceptionally difficult because of the complexity of social, cultural and biological factors involved in defining sickness. For that reason historical demographers tend to retreat back to mortality data as the best proxy for gauging ill health. ${ }^{15}$ However, the causes of death were not necessarily those which forced premature retirement from work, and therefore we need to consider other evidence to understand the pattern occupational health. The pension records allow us to do this and have several advantages over friendly society registers that other scholars have used to examine patterns of morbidity. ${ }^{16}$ First, there was a national and centralised arrangement for the systematic recording of ill health using standard forms. ${ }^{17}$ Medical officers for each Post Office district were instructed to note down in a journal details of episodes of ill health which were forwarded to the Chief Medical Officer in London, who was responsible for amalgamating and publishing the data in his annual report. Until the 1890s, by which time the workforce had grown too large, the Postmaster General

\footnotetext{
${ }^{14}$ Although it is apparent that the Chief Medical Officer was required to produce an annual report, these have not survived for the period. From 1891s they have survived and have been used to calculate the prevalence of sickness by P. J. Taylor and P. Burridge, 'Trends in death, disablement and sickness absence in the British Post Office since 1891', British Journal of Industrial Medicine, 39, (Feb., 1982), 1-10.

${ }^{15}$ The cultural context in which morbidity is defined is explores further in S. Ryan Johansson, 'The health transition: the cultural inflation of morbidity during the decline of mortality', Health Transition Review 1 (1991), 39-65.

${ }^{16}$ For a review of friendly society data see C. Edwards, M. Gorsky, B. Harris and A. Hinde, 'Sickness, insurance and health: assessing trends in morbidity through friendly society records' Annales de démographie historique, 105 (2003), 131-167; B. Harris, M. Gorsky, A Guntupalli and A. Hinde, 'Ageing, sickness and health in England and Wales during the mortality transition', Social History of Medicine 24 (2011), 643-665.

${ }^{17}$ See POST 64.7 General instructions issued to medical officers December 1880.
} 
was responsible for personally deciding on whether or not to grant a pension on grounds of ill health, based on the recommendation of the Chief Medical Officer. Although local variations undoubtedly existed, nevertheless this level of central scrutiny added a layer of checking that was largely absent from the friendly societies. Secondly, because of the importance of pensions in the Post Office, evidence of ill health was recorded for all workers from the start of their employment, allowing for the analysis of sickness in the entire workforce to take place from mid-century. Providing workers remained in Post Office employment for ten years, they would then become eligible for a pension and would therefore have appeared in the records. As the workforce grew, the number of pensioners increased from 178 in 1861 to 866 by $1900 .{ }^{18}$ Thirdly, although providing good evidence of the prevalence of ill health, friendly society records often fail to provide information on causality until much later in the century. It was not until 1892, for example, that the Hampshire Friendly Society began to note the cause of sickness but even after 1900, as Riley notes for other friendly society registers, it was not uncommon for the diagnosis column to be left blank or for a description of symptoms to be inserted instead. ${ }^{19}$ Fourthly, unlike many friendly society records, the pensions data contains information on employment for all eligible workers and this allows us to explore the relationships between occupation and ill health. Finally, because of the fitness requirements prior to being employed, the Post Office data does not suffer from the problem of adverse selection, whereby the availability of sickness pay attracts those who are most likely to make a claim, as might be argued was the case for friendly societies. ${ }^{20}$ Although the pensions data are not without problems, not least of which are the sometimes cursory descriptions of ill health,

\footnotetext{
${ }^{18} 1861$ figure from sample; 1900 figure from [Cd. 333] Forty sixth report of the Postmaster General on the Post Office, 21. These figures do not include women who were forced to retire from work after marriage.

${ }^{19}$ See James C. Riley, Sick Not Dead: the health of British workingmen during the mortality decline (London: John Hopkins University Press, 1997), 191-192; M. Gorsky, B. Harris, and A. Hinde, 'Age, sickness and longevity in the late nineteenth and early twentieth centuries: evidence from the Hampshire Friendly Society', Social Science History, 2006, 30 (4), 571-600.

${ }^{20}$ This point is made in J. F. Murray, The Origins of American Health Insurance: A History of Industrial Sickness Funds (London, Yale University Press, 2003), 12. Friendly societies sought to limit this possibility by imposing restrictions on who could be members and how often and when they could claim benefits, and by checking on the validity of claims. See Riley, Sick, Not Dead, 99-104.
} 
nevertheless they provide us with opportunities to examine sickness for the established workforce over time, taking account of age, gender, type of employment and place of work, and for a period when other evidence is largely lacking.

\section{Health and Retirement in the Post Office}

Details from the pension registers have been collected for all individuals who retired in 1861, 1871, 1881 and 1891 and the demographic characteristics of this sample are provided in Table 1 broken down by age and gender. The growing number of pensioners reflect both the expansion of the postal workforce as well as changes in eligibility that extended pension rights to a wider set of employees. After 1871 the records also show the increasing importance of women, a large number of whom were employed as telegraphists in London and other large cities. The data also shows the average age of pensioners, which was consistently below sixty, suggesting that reaching retirement age was not the only, or indeed the main, reason for having to leave work.

[INSERT TABLE 1 HERE]

Despite being passed fit at the start of their employment, and being able to access free medical care while they were employed, postal workers had some of the worst health outcomes of all civil servants. Repeated and prolonged bouts of sickness were more common in the Post Office than in other branches of the Civil Service, and were more often the reason for absences from work and premature retirement. From letter carriers who trudged through heavily polluted city air, to rural messengers exposed for long periods to the elements, and from telegraphists to sorters who worked at night in dusty, poorly lit and ill ventilated offices, the postal worker - primarily men but, as the century progressed an increasing number of women - experienced anything but good health. 
The significance of ill health is hinted at by the age structure of pensioners shown in table 2 which indicates that in all years, except 1861, workers tended to retire well before the age of 60 , suggesting that receiving a pension was, in the majority of cases, not because they had reached retirement age but rather because they had to leave work prematurely for other reasons, often to do with ill health. ${ }^{21}$ Of the 1,230 individual pension records in the sample, 701 (57 per cent) contained a reference to ill health as the cause or, at least, the partial cause of retirement from work. The remainder was largely due to old age: 415 referred to having reached 60 years; 49 to reaching 65 , and 42 to redundancy with a further 15 either not specified or due to other reasons. Bearing in mind that the pension records only refer to those who were forced to leave the Post Office for one reason or the other, the amount of ill health that was noted was part of a much larger problem of sickness-related absences from work.

[INSERT TABLE 2 HERE]

III health as a cause of retirement was not uncommon in the Civil Service but it was of greatest significance in the Post Office. Reviewing the pattern of superannuation in the ten years ending in 1901, the Royal Commission on Superannuation in the Civil Service compared the Post Office with other branches of the Civil Service and found that ill health was much more significant (See Figure 1). Throughout the period, the evidence confirms that compared to all other branches of the Civil Service, ill health was the most important reason for retirement from the Post Office. In part, this was to do with the nature of the workforce and rate of growth: in a rapidly growing organisation with a relatively young workforce, the proportion of those retiring upon reaching 60 or more was always liable to be smaller than in other longer established sections where groups of workers were likely to have been older. In addition, however, the workplace conditions of postal employees, including irregular hours of work, lengthy night shifts, dusty offices and the outdoor nature of much

\footnotetext{
${ }^{21}$ The jump in the number of over 60s retiring in 1891 was because under provisions of the Order in Council of 15 August 1890 civil servants over 65 were forced to retire, whether or not they wished to do so.
} 
Post Office work, exposed a far greater proportion of the workforce to specific hazards, be it the impact of shift work on the body, the strain that working at night in poorly lit sorting offices placed on eyesight, and the effect of the elements, all of which took their toll on worker's health. ${ }^{22}$ There was no one reason why postal workers had relatively high rates of sickness, noted Francis Salisbury, the Liverpool postmaster in 1903 , but rather a combination of factors arising from '... the trying nature of a good deal of the work, the exposure, continually changing hours of duties, and working together in crowded rooms. ${ }^{23}$

Compared to many of the more hazardous industrial trades, working in the Post Office was not particularly dangerous but there were nevertheless numerous occupational risks. In his 1856 annual report, Dr Waller Lewis thought that draughty corridors in the main London Post Office building at St Martins-Le-Grand were the reason for the relatively high incidence of respiratory illness in the workforce. Rheumatism, too, was very common with nearly half the workforce under his charge having received medical assistance for this complaint over a six month period. ${ }^{24}$ Workers appearing before the 1897 Parliamentary committee on Post Office establishments complained about the problems they encountered in different branches of employment. For telegraphists, working long hours in cramped conditions performing multiple clicks on telegraph machines not only led to the repetitive strain injury known as 'telegraphist's cramp' but, it was claimed, was also the cause of a variety of nervous complaints. ${ }^{25}$ Letter carriers and sorters also suffered from having to work

\footnotetext{
${ }^{22}$ Shift work is associated with poorer health outcomes, including mental health. See Ana-Claudia Bara and Sara Arber, 'Working shifts and mental health - findings from the British Household Panel Survey (1995-2005)', Scandinavian Journal of Work Environment \& Health, 2009, 35, 361-367; Manav V. Vyas et al., 'Shift work and vascular events: systematic review and meta-analysis', British Medical Journal, 26 July 2012, 365, 1-11. The inhalation of dust was seen at the time as a particular problem of occupational health. See J. T. Arlidge, The Hygiene, Diseases and Mortality of Occupations, 245-421.

${ }^{23} 1903$ [Cd. 1745] Report from the Royal Commission on Superannuation in the Civil Service, q. 2936.

${ }^{24} 1856$ [Cd. 2048] Second report of the Postmaster General on the Post Office, Appendix I: Medical Officer's First Periodical Report (Dr Waller Lewis), 76.

${ }^{25} 1897$ [Cd. 163] Post Office Establishments: copy of evidence (with indices, summaries and appendices) taken before the committee on Post Office establishments, q. 9-18, 2599, 2612, 2644. The British Medical Journal noted in 1909 that this condition was considered to be an occupational illness. See 'One who has had to suffer', 'The Postmaster General and our profession', British Medical Journal, 10 July 1909, 111-112. Interest in the social causes of insanity, including excitement of the nervous system, was of growing importance in
} 
irregular split shifts that required them to attend work at 4 or 5 am to sort and deliver the morning mail and again at $5 \mathrm{pm}$ to deal with the evening delivery, which led to chronic sleep deprivation, irregular meals and, as a result, poor health. This was particularly true in London where the system was most common and where workers often lived several miles away from their place of employment. ${ }^{26}$ Both the nature of the work, the way in which it was managed, and its location, therefore, took a toll on worker's bodies as well as on their minds.

\section{[INSERT FIGURE 1 HERE]}

The impact of ill health is evident in the pension data which record, as Table 3 shows that the main reason for retiring from the Post Office was on grounds of ill health. In $1861 \mathrm{Dr}$ Waller Lewis, the first medical officer at the Post Office, noted in his annual report on the health of workers in London that 14 out of 19 letter carriers at the central headquarters who had received a pension in that year had retired on grounds of health and this pattern was repeated elsewhere. In the nine other district offices in London, which had recently come under his control, 49 out of 50 letter carriers who retired did so because of poor health. ${ }^{27}$ In 1871, the Postmaster General's annual report noted that less than half those granted a pension were above 60 years old, suggesting that ill health was a more common reason for retiring from service than age alone. Of the 188 officers pensioned in England in 1870 , only 86 were aged 60 or above. ${ }^{28}$ By the 1890 s little had changed, with about 70 per cent of

psychiatric medicine during the period covered here. See L. J. Ray, 'Models of madness in Victorian asylum practice', European Journal of Sociology 22 (1981), 229-264; W. Bynum, A. Hardy, S. Jacyna and C. Lawrence and E. M. Tansey, The Western Medical Tradition 1800 to 2000 (Cambridge: Cambridge University Press, 2006), 200-202.

${ }^{26}$ The Times, 7 May 1860.

${ }^{27} 1862$ [Cd. 2984] Eighth report of the Postmaster General on the Post Office: Appendix N, Extracts from the medical report upon the London offices for the year 1861, 50, 73.

${ }^{28} 1871$ [Cd. 438] Seventeenth report of the Postmaster General, on the Post Office, 24. 
retirements due to ill health. ${ }^{29}$ Taken as a whole, therefore, ill health was the main cause of retirement from work and remained so throughout the century.

[INSERT TABLE 3 HERE]

\section{The Prevalence of Sickness}

The analysis of morbidity by Riley and other scholars, together with contemporary opinion, suggest that the prevalence of sickness, defined as the amount of sick-time experienced by the population at risk over a given time period, increased during the course of the nineteenth century, though there is little agreement as to the causes. ${ }^{30}$ Over time, the pension evidence also suggests that the amount of absence because of sickness rose. ${ }^{31}$ Table 4 shows the extent of sickness related absence from work in the ten years prior to retirement for 1861, 1871, 1881 and 1891 . The figures indicate that the sick rate for those pensioned off rose substantially, from around 7.7 days a year in 1861 to 14.3 in 1891. For the latter year, $\operatorname{Dr}$ Cecil Roberts noted that the male sickness rate for the entire permanent workforce was 8.9 days and for women 15.7 days. Older workers, who were more likely to appear in the pension records, tended to have longer absences than their younger colleagues, and this is the reason for the differential rates between pensioners and the workforce as a whole. ${ }^{32}$

The rise in the prevalence of sickness in the pension records mirrors the pattern found for members of various English friendly societies, as well as for workers in other countries. Explanations of the increasing prevalence of sickness revolve around two sets of causes, epidemiological and behavioural, with little agreement about which was most important. The epidemiological view

\footnotetext{
${ }^{29} 1898$ [Cd. 9022] Forty-fourth report of the Postmaster General on the Post Office, 30. See also the evidence of Sir George Murray, Secretary to the Post Office, in 1903 [Cd. 1745] Report of the Commission on Superannuation in the Civil Service, q. 4835-4840.

${ }^{30}$ This definition is taken from Harris et al, Ageing, sickness and health...', 640.

${ }^{31}$ See J. Riley, 'Why sickness and death rates do not move parallel to one another over time', Social History of Medicine, 12(1992); J. Riley, Sick, Not Dead; Edwards et al, , 'Sickness, insurance and health... '; Gorsky et al, 'Age, sickness and longevity in the late nineteenth and early twentieth centuries: evidence from the Hampshire Friendly Society', Social Science History 30 (2006), 571-600. For the most recent summary of the argument see Harris et al, 'Ageing, sickness and health...'.

${ }^{32}$ See POST 64/80 Post Office Medical Services and Morbidity Statistics, Dr Cecil Roberts (reprinted from the Monthly Bulletin of the Ministry of Health and Public Health Laboratory Service, September 1948), 186-190.
} 
argues that the changes were the result of shifts in longevity, leading to a higher incidence of chronic illness associated with old age. As the membership of insurance schemes aged, so the amount of time taken off for sickness by older subscribers increased. Riley, in particular, attributes the rising prevalence of sickness claims in British friendly societies to this shift. ${ }^{33}$ Other studies using friendly society records have also noted that the prevalence of sickness increased with the age of the membership, particularly noticeable with cohorts above the age of $60 .{ }^{34}$ By contrast, those who argue that behavioural factors, including malingering, amongst members of insurance schemes were more important in explaining prevalence rates point to changing attitudes to illness and a greater willingness to make a claim for sickness. ${ }^{35}$ Murray points out, for example, that in different European sickness insurance schemes, the prevalence and duration of claims appeared to increase with the scale of sickness payment. ${ }^{36}$ In other words, workers were more likely to report sick if they knew that they would receive benefits.

Determining the relative importance of these broad causal relationships is beyond the scope of this paper. However, the fact that the average age of Post Office pensioners hardly changed over the period: those who retired in 1891 were on average five years younger than those in 1861 and a year younger than those retiring in 1871 , and therefore age is unlikely to have been a factor in explaining the increased prevalence of sickness. This suggests that we need to consider other factors as the likely reasons for the lengthening amount of sickness leave including the compositional changes in the workforce, environmental changes relating to the workplace and living conditions, epidemiological changes concerning differences in types of ill health leading to retirement, and

\footnotetext{
${ }^{33}$ See Riley, Sick, not Dead, 171-187..34. Riley, 'Why sickness and death rates do not move parallel to one another over time', Social History of Medicine, 12(1992), 101-124; Gorsky et al, 'Age, sickness and longevity...', 578-86.

${ }^{34} \mathrm{~J}$. Riley, 'Why sickness and death rates do not move parallel to one another over time', Social History of Medicine, 12(1992), 101-124; Gorsky et al, 'Age, sickness and longevity...' , 578-86.

${ }^{35}$ This argument is explored in S. Ryan Johansson, 'The health transition...'. See also J. F. Murray, The Origins of American Health Insurance: A History of Industrial Sickness Funds (London, Yale University Press, 2003) ${ }^{36}$ See J. F. Murray, The Origins of American Health Insurance: A History of Industrial Sickness Funds (London, Yale University Press, 2003), 60-61.
} 
institutional changes in pension policy, sickness pay, the recording of sickness and worker's propensity to make a claim.

[INSERT TABLE 4 HERE]

\section{i. Composition of the workforce}

The composition of the workforce, including gender, was an important consideration in explaining changes in the prevalence of ill health in the Post office. In 1870 the Post Office took over the telegraph companies and with it a large number of female telegraphists. In the following years, further efforts were made to recruit more women to work in the Post Office and both the number and proportion employed began to increase from the 1870 s onwards. ${ }^{37}$ In 1880 , the first date for which figures were provided, women comprised 4.9 per cent of the established workforce but by 1901 this proportion had risen to over 16 per cent. ${ }^{38}$ Of these a large number were employed as telegraphists in London and other large cities where they worked in close proximity to colleagues, making the transmission of infectious disease more likely (Figure 2). ${ }^{39}$

The growing feminisation of the workforce had an impact on the reported pattern of absences since, for a variety of reasons, women tended to have more days off than men. ${ }^{40}$ In 1894 , female workers in twenty provincial post offices, in London and in the Central Telegraph Office had on average between 14.3 and 15.3 days off sick compared to between 8 and 8.3 for men ${ }^{41}$ In the following year, the Postmaster General noted in his annual report that for the entire workforce on average women

\footnotetext{
${ }^{37} 1873[\mathrm{Cd} 816]$ Nineteenth Annual Report of the Postmaster General on the Post Office, 15.

${ }^{38} 1881$ [Cd. 3006] Twenty seventh Annual Report of the Postmaster General on the Post Office, 16; 1901 [Cd. 762] Forty seventh Annual Report of the Postmaster General on the Post Office, 20. ${ }^{39} 1895$ [Cd. 7852] Forty-first Annual Report of the Postmaster General on the Post Office, 5.

${ }^{40}$ POST 64/1, The Post Office Medical System, 144, 159-65.

${ }^{41} 1897$ [Cd.163] Post Office establishments. Return to an order of the Honourable the House of Commons, dated 6 April 1897;--for, copy 'of evidence (with indices, summaries, and appendices) taken before the committee on Post Office establishments', q. 3985. These figures correspond closely with those outlined by P. J. Taylor and P. Burridge, 'Trends in death, disablement and sickness absence in the British Post Office since 1891', British Journal of Industrial Medicine, 39, (Feb., 1982), 1-10.
} 
were absent for sickness on 12.2 days a year compared to 7.9 days for men. ${ }^{42}$ This disparity is matched by the pension evidence. Table 5 shows that for the sample of pensioners, which included a higher proportion of older employees who tended to have more time off than younger ones, the number of sick days in 1891 was 19.6 per year for women and 13.8 for men. These figures correspond closely to the pattern of sickness amongst members of friendly societies identified by Riley and others for similar periods. In Morcott (1841-1902) and Ablethorpe (1863-1892), an agricultural village in Rutland and a shoemaking and farming village in Northamptonshire respectively, the average number of days per year when male members claimed sickness benefit was 7.87 and 8.12. In Ashbourne, a Derbyshire textile town, between 1863 and 1914 members of the female only friendly society had an average of 20.41 days off sick per year. ${ }^{43}$ The prevalence of ill health in the Post Office matches closely the patterns found in these places.

\section{[INSERT TABLE 5 HERE]}

\section{[INSERT FIGURE 2 HERE]}

While feminisation of the workforce might account for the overall increase in the average prevalence of illness in the workforce as a whole, it cannot fully explain why men as well as women appeared to have more prolonged sickness absences as the period progressed. Three other factors might also have accounted for this trend: a change in the kinds of illness recorded in the pensions data that was likely to lead to lengthier periods of ill health; a shift in the location of work from more to less healthy places, making the incidence of disease more likely; and a change in the way that sickness absences were recorded.

\section{ii. Categories of Disease}

\footnotetext{
421895 [Cd. 7852] Forty-first Annual Report of the Postmaster General on the Post Office, 14.

43 J. Riley, 'Why sickness and death rates...', 116; Edwards et al, 'Sickness, insurance and health...', 143.
} 
Medical historians have suggested that the rising prevalence of ill health might have been associated with an epidemiological shift in the type of complaints away from infectious diseases such as cholera and typhus, more typical of early decades in the nineteenth century which tended to result in relatively rapid mortality, towards more chronic conditions that, although less likely to result in death, were nevertheless also likely to have resulted in longer periods of incapacity. In other words, as mortality decreased and the age at death rose, so ageing survivors suffered more frequent and longer bouts of ill health arising from longer term, chronic conditions. ${ }^{44}$

Identifying these trends in the pension records, however, is difficult, partly because the final reason for retirement was not necessarily the same as the cause of prior episodes of sickness absence from work, and partly because of the common problems of identifying disease from inadequate information. Post Office doctors were required to keep detailed records not just of the length of sickness absences but also the causes, and were expected to refer to their notes if the intention was to pension off an employee on grounds of incapacity to work. The classification of disease that Post Office doctors were required to follow matched closely the nosology developed by William Farr in the General Register Office, though his schema was designed to explain mortality rather than morbidity. ${ }^{45}$ However, repeated bouts of sickness absence over a period of time, usually up to 18 months but which could have been as long as three years, was a factor in deciding whether or not to pension off an employee. For that reason, additional categories were added by the Post Office to indicate conditions that would have incapacitated an employee from working, such as defective eyesight, delirium tremens, indigestion or gout - none of which was likely to end in death but all of which could have resulted in inability to continue working. The descriptions of ill health contained in the records, therefore, reflected an amalgamation of pragmatism and medical knowledge with entries including diseases and conditions that were relatively easy to identify, such as phthisis or

\footnotetext{
44 This argument is made by Riley $(1992 ; 1997)$ and Gorsky et al (2006).

45 The classification was issued to Post Office doctors by the Chief Medical Officer. See POST 64/1 The Post Office Medical System, Post Office doctor's medical rules, 1009-1010.
} 
bronchitis, together with more general descriptions such as 'weak lungs' or 'mental incapacity' that would have prevented an employee from being able to continue to work.

In order to explore the possibility that changing patterns of disease could have been responsible for the lengthening prevalence of ill health we have chosen to use the International Classification of Disease (ICD) 10 system which provides a more granular approach that categorises types of disease rather than causes of death. ${ }^{46}$ Descriptions of diseases or conditions contained in the pension records were very limited and it is therefore only possible to allocate them to broad disease categories. There is also the issue of co-morbidity where the recorded medical reason for being pensioned off could reflect a variety of different diseases. For these reasons, therefore, our findings come with the usual cautionary warnings about the dangers of retrospective diagnoses based on incomplete data.

Despite these difficulties, it is possible to distinguish shifts in diagnosis as shown in Table 6, though there is considerable variation across each sample year. In 1861 the most common reason for being pensioned off early was attributed to non-specific causes, such as 'worn out' or 'general debility'. In later years, perhaps as medical knowledge improved and diagnosis became more accurate, other causes became more prominent. Six major disease groups were responsible for over three quarters of premature retirement: musculoskeletal, diseases of the eye, infectious, circulatory and respiratory illnesses, and mental and behavioural disorders. However, of these disease groups, infectious (including tuberculosis), circulatory and respiratory diseases were amongst the most common causes of death in the population as a whole. In 1860, around a fifth of the total number of sickness absences in London district postal offices were due to tuberculosis, a wasting disease that

\footnotetext{
${ }^{46}$ The ICD 10 system was introduced by the World Health Organisation in 1992 and contains over 16,000 different classifications of disease. See http://www.who.int/classifications/icd/en/. Medical historians have also used the ICD 10 system to explore morbidity in the past.
} 
can take several years to reach its final stages and therefore subjected sufferers to repeated bouts of ill health, and this figure remained fairly constant for the rest of the century. ${ }^{47}$ It was certainly a concern for the Post Office throughout the period and was consistently mentioned in the annual reports submitted to the Postmaster General by the Chief Medical Officer. ${ }^{48}$ Pulmonary tuberculosis and chronic respiratory diseases such as bronchitis and asthma were also common reasons for retiring from work. The two sets of diseases, however, differ in their causal mechanisms: consumption is a bacterial infection spread by victims inhaling the tubercule bacterium from existing sufferers whilst other respiratory diseases such as chronic bronchitis can be viral or bacterial in origin. Both, however, can be exacerbated by exposure to substances that irritate the lungs, such as dust or smoke. But taken together, tuberculosis and respiratory disease also accounted for around 25 per cent of all age mortality throughout the second half of the century and therefore their incidence within the Post Office workforce was likely to have reflected broader environmental factors rather than any specific risks arising from employment. ${ }^{49}$ Overcrowded working conditions and dusty offices might have encouraged the spread of such diseases but by themselves were unlikely to have been the main risk factors in their incidence in the first place.

However, the three remaining disease groups, musculoskeletal, diseases of the eye and mental and behavioural disorders, though they did not necessarily lead to death, were important, accounting for between around 30 and 40 per cent of health-related retirements, and here occupational risk played a role, albeit tempered by other factors. In all years except 1891, the most common set of

\footnotetext{
${ }^{47} 1897$ (Cd. 163) Post Office establishments. Return to an order of the Honourable the House of Commons, dated 6 April 1897 (with indices, summaries, and appendices) taken before the committee on Post Office Establishments, q. 6476-6484.

${ }^{48}$ See The Lancet, 'Stamping out consumption: what the Post Office has done in ten years', (9 September 1905), 791-792.

${ }^{49}$ D. Brunton, 'Dealing with disease in populations: public health, 1830-1880', in Medicine Transformed: health, disease and society in Europe 1800-1930 edited by D. Brunton (Manchester, Manchester University Press, 2004), 205. This was also the conclusion reached at the time. See T.D. Lister and C. H. Garland, 'Tuberculosis and the postal service', British Journal of Tuberculosis, 2 (1908), 177-181. For the struggle to link tuberculosis to occupational conditions see A. Mclvor, 'Germs at work: establishing tuberculosis as an occupational disease in Britain, c.1900-1951', Social History of Medicine 25 (2012)812-829.
} 
diseases noted in the pension records were musculoskeletal conditions. Given the outdoor and physically demanding nature of delivering letters and parcels, it is hardly surprising that musculoskeletal complaints, such as rheumatism and arthritis, were a significant reason for retirement, particularly in rural areas where postmen were outdoors for long periods of time and had to walk lengthy rounds carrying heavy sacks. Efforts to address this so called 'postman's complaint' included the introduction in 1861 of Inverness coats to replace Mackintosh capes which provided better protection for letter carriers and messengers (Figure 4). ${ }^{50}$ Even so, the strain on postmen's bodies from having to carry heavy loads was significant and although they were expected to be able to carry sacks of $66 \mathrm{lbs}(30 \mathrm{~kg})$, on occasions they would have to carry significantly heavier weights with corresponding impact on their body. ${ }^{51}$

The strain, too, on workers' eyes was evident from the relatively large number of enforced retirements arising from defective, impaired or failing eyesight or vision. Although many conditions could lead to poor eyesight, eye strain arising from having to decipher small handwritten letters in dim, gas-lit offices, often at night, for long periods of time could have exacerbated the problems that workers suffered. The introduction of electric lighting in the Post Office, beginning in Glasgow in 1880 , would have improved illumination, and therefore reduce eye strain, as well as reduce noxious emissions from gas lamps. ${ }^{52}$ Electric lighting spread rapidly and in 1882 the central office at St Martin Le Grande was lit with 59 incandescent bulbs using Thomas Edison's new system..$^{53}$ The effect was

\footnotetext{
${ }^{50} 1861$ [Cd. 2899] Seventh annual report of the Postmaster General, Appendix J, Extracts from the Medical Officer's Report upon the London offices for the year 1860, 46.

${ }^{51}$ In 1858 candidates for the position of letter carrier had to be able to lift two weights of $66 \mathrm{lbs}$ each. POST 64/1, The Post Office Medical System, 974-983, though the physical requirements changed over time. See also 1897 (Cd. 163) Post Office establishments. Return to an order of the Honourable the House of Commons, dated 6 April 1897 (with indices, summaries, and appendices) taken before the committee on Post Office Establishments, q. 7935. The current weight limit for postal sacks is around $53 \mathrm{lbs}(16 \mathrm{~kg})$. See https://www.royalmailchat.co.uk/community/viewtopic.php?f=56\&t=70790 (accessed 15 May 2018) ${ }^{52}$ Burning coal gas also produced noxious fumes arising from a combination of hydrogen, methane, carbon monoxide and sulphur.

${ }^{53}$ Glasgow Herald 13 December 1880
} 
thought to be remarkable and immediate, as the Edinburgh Evening News reported: "An even light without any shadow was thrown over the tables, while the atmosphere, previously heated by gas, sensibly diminished in temperature, even in the short space of about 20 minutes.". ${ }^{54}$ Perhaps as a result, by 1891 there were fewer eye problems recorded as the reason for retirement.

However, eye disease was relatively common in the population at large, including a set of conditions known as 'ophthalmia', used to describe a variety of inflammatory and often highly contagious infections of the eye, and trachoma, which was characterised by repeated bouts of inflammation, ultimately leading to blindness. ${ }^{55}$ Although neither of these medical terms were used explicitly in the pensions records, both sets of conditions could have been responsible for the numerous descriptions of eye complaints noted by Post Office doctors. Eyes were certainly strained in the pursuit of Post Office work and overcrowded workplaces could have contributed to the spread of these conditions, but since these kinds of infections were also common outside the Post Office, blame for their existence cannot be attributed purely to conditions at work although they were an important cause of early retirement.

Finally, mental and behavioural disorders, including diagnoses that loosely describe various forms of mental illness such as 'nervous debility' or 'mental incapacity', were comparatively important reasons for premature retirement. ${ }^{56}$ However, the causal relationships between these kinds of disorders and mental illness were poorly understood and descriptions of symptoms in the pension

\footnotetext{
${ }^{54}$ Edinburgh Evening News 23 August 1882.

55 See C. Margo and L Harman, 'Charles Dickens, trachoma, and blindness in pre-Victorian England', Survey of Ophthalmology 63 (2018), 275-80. Awareness of different forms of ophthalmia came about as a result of greater specialization and improved medical instruments. See L. Davidson, “'Identities ascertained': British ophthalmology in the first half of the nineteenth century', Social History of Medicine, 9 (1996), 313-333. In the 1860s, opthalmascopes were still relatively new but became of increasing importance in the diagnosis of eye disease. See J. V. Solomon, 'Notes on the surgery of the nineteenth century and the ophthalmoscope', The British Medical Journal, 2, 396 (Aug. 1, 1868), 103-104.

${ }^{56}$ Nervous debility was a widely used term in the mid-nineteenth century to describe a wide range of symptoms amenable to various dubious treatments. See J. Knelman, 'Nervous debility: a disorder made to order.' Victorian Review, 22 (1996), 32-41.
} 
records were suitably vague, referring primarily not to the illness itself but rather the impact on the ability to work. Some of these instances could have been associated with co-morbidity, including diseases such as syphilis, and the early onset of various forms of degenerative conditions more common today, but others could have been the result of overly stressful working conditions, particularly in certain kinds of postal work. Telegraphists, for example, were thought to suffer from nervous complaints more than other workers as a result of having to work long hours at high intensity, needing to respond rapidly and accurately to a series of repeated clicks coming from a machine.$^{57}$ Pressure also existed, however, in other sections including travelling postmen who sorted the mail on trains as well as those working at night in sorting offices who had to deal with a huge volume of mail in a very short space of time. In both sets of instances, noise and intensity of work combined to generate stressful conditions that impacted on workers' health. ${ }^{58}$

[INSERT FIGURE 3 HERE]

[INSERT TABLE 6]

\section{iii. Geographies of III Health}

The final environmental reason that might have helped to account for the lengthening of sicknessrelated absences was a shift from more healthy working and living environments to less healthy ones, specifically a move from rural to more urban workplaces. Differential mortality rates in the nineteenth century between urban and rural places are well documented, and therefore as the number of postal workers increased in London and large cities relative to the countryside, there was

\footnotetext{
${ }^{57}$ See The Lancet, 1 August 1885; 1897 (Cd. 163) Post Office establishments..., q. 2612, 2640, 4497.

${ }^{58}$ There is an extensive literature on the relationships between psychological stress and co-morbidities. See, for example, Y. H. Lin, C. Y. Chen and Lu, S.Y., 'Physical discomfort and psychosocial job stress among male and female operators at telecommunication call centers in Taiwan', Applied Ergonomics. 40 (4) (2009), 561-568; A. Prior et al, 'The association between perceived stress and mortality among people with multimorbidity: a prospective population-based cohort study', American Journal of Epidemiology, 184 (2016), 199-210; D. Vancampfort et al, 'Perceived stress and its relationship with chronic medical conditions and multimorbidity among 229,293 community-dwelling adults in 44 low- and middle-income countries', American Journal of Epidemiology, 186 (2017), 979-989.
} 
the possibility that they were exposed to more hazardous living conditions that affected morbidity as well as mortality. Although advances in sanitation reduced the impact of water-borne diseases and infections in cities, progress in improving urban air quality was far more difficult to achieve and many of the respiratory and circulatory problems that plagued postal workers could have been exacerbated by these conditions. In London during the period, foggy days were associated with steep rises in mortality from respiratory and cardiovascular diseases. ${ }^{59}$ For urban postal workers, particularly letter carriers exposed to highly polluted air or sorters who worked for long hours in dusty and poorly lit sorting rooms, this geographical shift meant that a larger proportion of the workforce was exposed to poorer conditions arising from the concentration of postal work in London and other large and heavily polluted cities.

One way of understanding the impact of living conditions is to take account of the type of place as a surrogate for a range of environmental factors that would have affected health outcomes. In this analysis, we have chosen to use a four-fold classification based on size of place as a surrogate measure of 'urban-ness' - classifying each primary place of work either as London, urban (places with at least 100,000 population), town (places with a population of between 10,000 and 99,999 ) or rural (places with less than 10,000 people). ${ }^{60}$

\footnotetext{
${ }^{59}$ For the relationship between fog and mortality in London see W. W. Hanlon, 'London fog: a century of pollution and mortality, 1866-1965', National Bureau of Economic Research Working Paper 24488 (2018). Air pollution in general is explored by P. Brimblecombe and L. Makra, 'Selections from the history of environmental pollution, with special attention to air pollution. Part 2: From medieval times to the 19th century', International Journal of Environment and Pollution, 2005, 23, 351-367; Bill Luckin, "The heart and home of horror': The great London fogs of the late nineteenth century', Social History, 2003, 28, 31-48; Bill Luckin, Death and Survival in Urban Britain: diseases, pollution and environment 1800-1950 (London: I B Tauris, 2015 ); Stephen Mosley, Chimney of the World: smoke pollution in Victorian and Edwardian Manchester (Cambridge: White Horse Press, 2001); D. Stradling and P. Thorsheim. 'The smoke of great cities - British and American efforts to control air pollution, 1860-1914', Environmental History, 1999, 4, 6-31.

${ }^{60}$ The population was taken from Vision of Britain (http://www.visionofbritain.org.uk/) and referred to the census year that corresponded to the pension entry. Places were classified according first to the population in the poor law union district with the same name as the entry. Where places were not their own union, the next lower spatial unit was chosen. Places in Ireland and the Isle of Mann were identified in the relevant census abstracts.
} 
During the nineteenth century there were marked urban-rural differences in mortality, including death in old age, and this pattern appears to hold true in relation to the prevalence of ill health in the Post Office where the prevalence of sickness was closely related to the size of place.$^{61}$ As Figure 4 shows, during the period Post Office workers were far more likely to retire because of ill health in London and other large cities than in smaller towns and rural districts. Seventy per cent of those workers who were pensioned in London retired on grounds of ill health compared to 48.5 per cent in rural areas and over 50 per cent in towns. This pattern was matched also by the number of days off sick. Table 7 shows that the prevalence of ill health for male workers in London and other large urban areas was nearly twice that of smaller towns, and three times higher than in rural areas, despite the fact that the workforce was younger. The difference was even greater for female workers, though the numbers are much smaller. Place, according to this evidence, was more important than age in determining the prevalence of ill health; and workers in London and other large cities had far worse health outcomes than those living in in more rural locations.

[INSERT FIGURE 4 HERE]

[INSERT TABLE 7 HERE]

Geography, however, was overlain by other factors, including the composition of the workforce in large cities compared to other places. Gender might have had a part to play, since there were higher proportions of female workers in London and urban places than there were in towns and, especially, rural areas. In the early 1880s, for example, women made up between ten and thirteen ten per cent of the workforce in London, Edinburgh and Dublin, but only between five and eight per cent in the rest of England and Wales, Scotland and Ireland. ${ }^{62}$ However, the proportion of women is too small to account for the differences and therefore other factors are likely to have been more important. Nor

\footnotetext{
${ }^{61}$ See Robert Woods and Nicola Shelton, An Atlas of Victorian Mortality, (Liverpool: Liverpool University Press, 1997).

${ }^{62}$ The figures are calculated from the 1883 [Cd. 3703] Twenty-ninth report of the Postmaster General on the Post Office, Appendix E Staff of officers, 33-35.
} 
was age responsible for the differences between urban and rural places. The figures in Table 8 show the average number of days off for ill health in different places broken down by age group and these suggest that the effects of age were overlain by the characteristics of place. While younger workers in general tended to have longer absences arising from ill health - an issue that is also partially related to gender since greater numbers of young women were employed in large urban postal districts - there is a marked difference for each age group depending on the location of employment. ${ }^{63}$ Younger workers in London and other large cities, for example, had nearly double the number of sick days than their rural counterparts and for the older age group of 60 and above the difference was even greater. In other words, even when controlling for age, it appeared that geography mattered.

\section{[INSERT TABLE 8 HERE]}

Further evidence for the importance of place comes from comparing similar occupations in urban and rural areas. The main groups of workers in the Post Office and that were recorded in the pension records were associated with the delivery of mail, a type of work that involved similar kinds of physical activity. In London and other urban places, postal workers who delivered the mail were known as letter carriers, and in rural areas the term used was rural messenger. ${ }^{64}$ Table 9 compares the prevalence of ill health for these similar occupational groups, broken down by type of place. The pattern is essentially the same as described for the entire data set, namely much higher rates of ill health in London and other large urban centres compared to towns and rural places. Postmen in London and large cities had around three times more sickness-related absences than their rural counterparts, despite being younger.

\footnotetext{
63 This pattern runs counter to the trend found in the friendly society records, where sickness absence is positively correlated with age. It also runs counter to figures in Taylor and Burridge, 'Trends in death....' for later periods. Further research is needed to explore this counter-intuitive finding.

${ }^{64}$ After the Post Office took over delivering parcels in 1883 , letter carriers and rural messengers were called postmen. In practice the terms covered a range of occupations associated with delivering the post.
} 
In London, blame for this situation was placed on having to undertake split duties - two shifts of work spread across the day that ran from around 4am until 8am, and then again from 4.30pm to $8 p m$ - which, because of the distance that workers lived away from the main Post Office, meant very early starts, irregular meals and interrupted sleep. ${ }^{65}$ In 1897 Dr A H Wilson, the Chief Medical Officer, considered these split duties to be the main reason for the relatively high rates of illness, particular amongst younger men aged below 25 whom, he argued, had neither the constitution nor the good habits required to cope with the demands that irregular hours imposed. ${ }^{66}$ Like many other Post Office employees, John Fitzgerald, a first class sorter, complained about the effects of having to start work at 4 am stating that '... many men have had to leave the service because they have not been able to do this early morning attendance. It requires all the will a man is possessed of to get up morning after morning or every other morning at this unearthly hour'. ${ }^{67}$ This was a particular problem in London where dual shifts were more common and where workers were unable to afford to live close to the main Post Office in the City and therefore had to travel long distances to get to and from work. ${ }^{68}$

\section{[INSERT TABLE 9 HERE]}

Geography also influenced the kinds of ill health that forced premature retirement. Table 10 shows that the four main groups of diseases were musculoskeletal conditions, mental disorders, infectious and respiratory conditions. However, there were important differences in the incidence of disease categories, particularly between London and rural areas. Failing eyesight and mental illness, the latter defined broadly by terms such as 'nervous debility', 'nervous exhaustion', or 'mental

\footnotetext{
651897 [Cd. 163] Post Office establishments. Return to an order of the Honourable the House of Commons, dated 6 April 1897;--for, copy "of evidence (with indices, summaries, and appendices) taken before the committee on Post Office establishments." q. 9-16

66 Ibid., q. 6442-56, 6513-19.

67 Ibid, q. 558.

${ }^{68} \mathrm{lbid}$, q. 9-18, 6442-49, 6478, 6513-19.
} 
instability', were of much greater significance in London. Compared to the countryside, workers there were twice as likely to retire because of poor eyesight and five times more likely to leave because of mental or behavioural disorders. But in rural areas, where postmen had to travel longer distances to cover their rounds carrying heavy loads, musculoskeletal conditions were a more common reason for premature retirement.

Differential rates of diagnosis might have had an impact on these geographical divisions but the variation also points to specific problems concerning conditions of work and living that were more likely to occur in the capital than elsewhere. The concentration of telegraphists in London, in part might have accounted for this pattern. ${ }^{69}$ They suffered a form of repetitive strain injury known as telegraphist's cramp, which incapacitated workers for weeks at a time. ${ }^{70}$ They were also thought to suffer more from nervous disorders, an issue of increasing concern in the latter part of the nineteenth century. ${ }^{71}$ Charles Garland, a first class telegraphist with thirteen years' experience, noted in 1897 how the conditions of work 'combine to produce a nervous condition which may be defined as neurasthenic and which although not always resulting in serious mental disorders, materially impairs the efficiency of the staff causing much sick leave...' ${ }^{72}$. By contrast, Dr Arthur Wilson, the chief medical officer at the time, was more sceptical about the causes of absences, suggesting that they were not due to work, but to the '... effects of drink, financial worry, domestic worry, influenza, excessive venery, masturbation and reading for higher examinations after official hours' ${ }^{73}$

\footnotetext{
${ }^{69}$ Ibid., q. 2599,

${ }^{70}$ Ibid., q. 6557.

${ }^{71}$ See Lawrence, C, Medicine in the Making of Modern Britain 1700-1920 (London, Routledge, 1994), p 71.

721897 [Cd. 163] Post Office establishments, q. 2599.

${ }^{73}$ Ibid., q. 6556.
} 
Working conditions, however, rather than 'excessive venery' or 'masturbation' were more likely to have been the reason for the existence of stress-related illness in the workplace. The pressure of work in the main General Post Office at St Martins-le-Grand - an old and draughty building that grew increasingly unfit for purpose as the volume of mail grew - was also likely to have played a part in this. An investigation by The Times in 1860 commented on the lack of space, noting how closets had been converted to offices and extra rooms created by hanging tie rods to the ceiling. In the Circulation Office, it noted, '... light, and to a great extent ventilation also, are carefully excluded'.$^{74}$ Although the opening of a new General Post Office building opposite the old one in 1874 to accommodate the telegraph and other functions allowed some internal re-organisation of space in the old building, nevertheless complaints persisted, particularly in winter, about gas fumes and poor ventilation resulting in frequent headaches and respiratory illness. The introduction of electric lighting, discussed above, helped improve conditions but until then complaints from workers continued. ${ }^{75}$ Nor did the opening of the new building ease the pressure on space that the growing volume of mail generated. In the year ending 31 March 1880 over 310 million letters were delivered in London, nearly a third of the entire total for England and Wales but by 1890 the total had risen to around 518 million, placing immense pressure on both space and the workforce required to manage the post. ${ }^{76}$

The sheer volume and intensity of the mail impacted particularly harshly on letter sorters and postmen. The $6 \mathrm{pm}$ rush in London to catch the last post to the country, illustrated in Figure 5, was by far the busiest and an army of sorters worked throughout the night to get the mail out for the following day. Charles Dickens writing in Household Words in 1850 described the frenzied rush to get newspapers to the Post Office in time to catch the last free post:

\footnotetext{
74 The Times 29 March 1860.

75 British Medical Journal, vol. 2, no. 1249 (Dec. 6, 1884), p. 1149.

${ }^{76} 1890$ [Cd. 6170] Thirty-sixth report of the Postmaster General on the Post Office, Appendix A, 17;
} 
It was a quarter before six o'clock when they crossed the hall, six being the latest hour at which newspapers can be posted without fee. It was then just drizzling newspapers. The great window of that department being thrown open, the first black fringe of a thunder-cloud of newspapers, impending over the Post Office, was discharging itself fitfully-now in large drops, now in little; now in sudden plumps, now stopping altogether. By degrees it began to rain hard; by fast degrees the storm came on harder and harder, until it blew, rained, hailed, snowed, newspapers.

Henry Horsfall, a first class sorter who had worked in the Post Office since 1878, told the Tweedmouth Committee on Post Office Establishments in 1897 how in the evening shift he had to deal with this flood of mail. He stated that to keep to schedule, he would be expected to despatch between 2,000 and 3,000 letters in an hour and 25 minutes - equivalent to sorting about one letter every two or three seconds. ${ }^{77}$ Dealing with the volume and intensity of work was stressful and this was exacerbated by the irregular split duties that were required to cope with the ebb and flow of mail that took place early in the morning and again later in the evening. Under these circumstances, the relentless pressure of work in difficult conditions must have taken their toll on worker's minds as well as their bodies.

\section{iv. Reporting Sickness}

Finally, we have to consider institutional causes that might help to explain the changing prevalence of sickness, including how sick pay and sickness monitoring might have influenced the temporal and spatial patterns of sickness described above. Insurance schemes and sick pay create what John Murray has termed a 'moral hazard' by which the very availability of benefits designed to mitigate

\footnotetext{
771897 [Cd. 163] Post Office establishments. Return to an order of the Honourable the House of Commons, dated 6 April 1897, q. 294.
} 
the effects of ill health generate an incentive to reduce efforts to keep well. ${ }^{78} \ln$ this way, relatively generous rates of sick pay could have encouraged workers to absent themselves on spurious medical grounds - a view expressed by $\operatorname{Dr} \mathrm{A}$. H Wilson, the chief medical officer, in his evidence before the 1897 Tweedmouth Committee. ${ }^{79}$ The official regulations stipulated that a worker could not absent themselves on grounds of illness for more than a day without a medical certificate, which could only last for a week before re-certification was needed. To claim sickness pay, a private doctor's certificate could suffice but had to be countersigned by the Post Office doctor. ${ }^{80}$ Details of the absence were entered in the medical journal, included in an annual report and sent to the Chief Medical Officer but once certified sick, employees were then able to claim sickness pay. ${ }^{81}$

However, the availability of sick pay was complex, varying by place as well as by the type of job and grade of employee. ${ }^{82}$ Until the 1870 s differences in the rates of sick pay existed between some of the larger post office districts, such as London, Dublin, Liverpool and Manchester, and the rest of the country. ${ }^{83}$ From 1872 , however, greater uniformity was introduced across the Post Office for establishment workers who were employed on a permanent basis. From that time, established workers were entitled to full pay for six months and then half pay for a further six months. After a year, or if there was at least 12 months ill health within an 18 month periods, if there was no prospect of a permanent return to work, employees were likely to have been pensioned off providing they had served a full ten years in the Post Office. However, this practice was dependent on the Postmaster General who, it was noted, '...objected to the adoption of a general rule

\footnotetext{
78 See J. F. Murray, The Origins of American Health Insurance: A History of Industrial Sickness Funds (London, Yale University Press, 2003), 11, 47

791897 [Cd. 163] Post Office Establishments, q. 6607-6609.

${ }^{80}$ Burridge and Taylor, 'Trends in death... ', 3. Changes in the rates of sickness pay and the categories of workforce covered by the regulations altered over time. See POST 64/4 Sick leave conditions 1857-1902: memorandum.

${ }^{81}$ POST 64/1, Post Office Medical Service, 91-95; 269-270.

82 This is summarised in Taylor and Burridge,'Trends in death...', 4-5.

${ }^{83}$ Sick leave arrangements are outlined in POST 64/4 Memorandum comprising a brief history of sick leave conditions 1857-1902.
} 
respecting sick pay on the ground that such a general rule might induce officers to malinger...' and who personally reviewed pension claims relating to ill health. ${ }^{84}$ This policy remained in place until 1890 , by which time the workforce was far too large for personal scrutiny to be practical. From then onwards, some discretion was allowed to extend the period of absence for up to three years. In the following years more workers, including those who were only employed part time or on temporary contracts were able to benefit from these arrangements and the extension of sick pay to the wider workforce could have resulted in larger numbers of workers towards the end of the period being able to take time off for sickness or to remain off sick for longer prior to retirement. ${ }^{85}$

To counteract this temptation, medical officers employed by the Post Office were charged with identifying and reporting malingering and their presence was thought to have reduced the problem. Workers complained that doctors employed by the Post Office were stricter in their interpretation of sickness than other private practitioners and were more likely to act in the interests of their employers than for the benefit of the employees. ${ }^{86}$ In July 1886 Sir Arthur Blackwood, Secretary to the Post Office, wrote to the Postmaster General in relation to a request to extend the service that 'It is impossible to exaggerate the importance of this system of Medical Supervision as a means of checking absence on a false or insufficient plea of illness and of arresting illness in its incipient stages, whereby a prolonged absence with all the attendant inconvenience and expense of providing for the absentee's duties may be avoided. ${ }^{87}$ Post Office doctors were expected to '... constantly report upon the health of individuals - the probability or otherwise of their ability to render efficient service in the future, the desirability or otherwise of their retirement before the statutory age' ${ }^{88}$

\footnotetext{
84 POST 64.4, Sick leave conditions..., 2.

85 See POST 64/4 Sick leave conditions, 25-33.

${ }^{86}$ See 1897 [Cd. 163] Post Office establishments. Return to an order of the Honourable the House of Commons, dated 6 April 1897, q. 679-684, 10036-10074. See also Taylor and Burridge, 'Trends in death... ', 3. Murray terms this issue the 'principal-agent conflict'. See J. F. Murray, Origins of American Health Insurance, 50. 87 POST 64/1, Post Office Medical Service, 304.

${ }^{88}$ G. Mason, 'The Postmaster-General and the Medical Profession', British Medical Journal 31 July 1909, $295-$ 296.
} 
Furthermore, the introduction of good conduct 'stripes' to indicate high levels of performance accompanied by improved pay, was used as a way of both rewarding but also disciplining workers. Postmen could be awarded up to 3 stripes, amounting to an extra 3s per week, which in London was equivalent to between 9 and 12 per cent of basic pay and elsewhere between about 11 and 13 per cent. ${ }^{89}$ However, persistent absences were liable to lead to disciplinary action, demotion and possibly even dismissal. Losing stripes, therefore carried a financial penalty that could outweigh any material benefits workers might expect from repeatedly signing off sick.

However, disentangling the complex interplay of compositional, environmental and institutional factors is exceptionally difficult. In London, where sick pay arrangements had been in operation from an early stage, the length of time off as a result of sickness was highest, even though medical attendance was introduced earlier than in many other places, hinting that the fears expressed by Dr Wilson had an element of truth. But it was also there that a larger proportion of women were employed which was a factors in explaining higher rates of sickness absence. There were also environmental reasons why ill health was also more likely to be a problem in London than elsewhere, not least of which were the problems generated by split shifts. Disentangling the effects of these contributory factors, therefore, invites caution and further work is needed before coming to a conclusion about the relative importance of one set of factors over another in explaining lengthening absences from work.

\section{Conclusion}

Very few postal workers died because of their job. Accidents were relatively rare and there were no obvious industrial diseases that led to disfigurement or disability to capture the public imagination.

\footnotetext{
${ }^{89}$ There were three levels of good conduct stripes that involved additional weekly payments of between $1 \mathrm{~s}$ and 3s respectively. See 1890 [Cd 410] Postmen's pay and allowances (London and other large towns).
} 
Rather, health risks in the Post Office were more insidious and unspectacular, operating over longer periods and in less obvious ways. 'The work of a postman,' noted Dr Sir B W Richardson in 1890, 'is one of continuous busy go-round, he is on his feet during the whole of his working hours. The result is that the postman wears out fast' ${ }^{90}$ Having been certified fit to take on responsibilities in the Post Office, workers could look forward to a long period of employment, and for those who stayed for at least ten years, to the prospect of a pension upon reaching sixty or sixty five years of age. There were benefits to working for the Post Office. Established workers were able to take relatively generous amounts of sick pay, and this was gradually extended to other sections of the workforce. Medical care was provided free for established workers and later on to others. Workplaces were modernised, with electric lighting and new purpose built offices designed to cope with the ever growing amount of mail. But workers did wear out fast and relatively few continued to be employed until they reached superannuation.

For many workers, indeed the majority, failing health cut short their period of employment, more so in the Post Office than in other branches of the Civil Service. Although working for the Post Office was not nearly as dangerous as working in mining or fishing, it nevertheless had its own set of health hazards. Walking long distances in inclement weather carrying heavy mail sacks, trudging repeatedly through polluted urban environments delivering the mail, working on poorly designed telegraph machines in cramped positions, or even working long night shifts in ill-lit and poorly ventilated sorting offices, all took their toll on the minds and bodies of the workforce. Whether it was because of defective eyesight or nervous debility, chronic respiratory disease, or rheumatism and arthritis, workers in the Post Office throughout the period were more likely to retire on grounds of ill health than they were of old age.

\footnotetext{
${ }^{90}$ Quoted in 1897 [Cd. 163] Post Office establishments. Return to an order of the Honourable the House of Commons, dated 6 April 1897, q. 7939.
} 
Over the period the prevalance of ill health in the workforce appeared to increase, a phenomenon that other scholars have also noted. ${ }^{91}$ The lengthening periods of absence through ill health, however, are difficult to explain and no single set of factors is likely to have been responsible. Changes in the prevalence of ill health were partly to do with the changing composition of the workforce, particularly the growing numbers of women employed in the service. But feminisation was not the sole reason. Shifts from rural to urban patterns of work and living also accounted for different kinds of ill health, acting as a reminder that work by itself did not necessarily make workers ill. Living conditions, particularly poor air quality, took their toll on urban dwellers irrespective of whether or not they worked in the Post Office, and overcrowded living conditions fostered the spread of infectious diseases. The availability of sick pay for larger numbers of the workforce, too, could have acted as an inducement to take time off, though the growing number of medical officers acted as a check on malingering, reinforced by institutional systems of discipline and reward.

What this research has shown is that explaining health outcomes in the workplace is exceptionally complex, particularly where they related less to death and disability arising from accidents or industrial diseases and more to the 'insidious and unspectacular' nature of much occupational ill health. Relatively few conditions could be ascribed directly to working for the Post Office, though several might have been exacerbated by conditions in the workplace itself. By exploring these issues in the Post Office, we can reocgnise the importance of understanding the inter-relationships between sets of confounding factors: the composition of the workforce, the institutional arrangements regarding sick pay, behavioural decisions by workers, the material conditions relating to work, medical knowledge and the impact of living conditions. In such a large organisation, with such varied kinds of work, operating across the entire country, it is hardly surprising that there was no single cause of occupational ill health in the Post Office but rather a combination of factors that interacted with the characteristics of people, place and time to generate specific health outcomes

\footnotetext{
${ }^{91}$ See Riley, J., Sick, Not Dead, pp. 154-156.
} 
for different sections of the workforce. Unspectacular as these outcomes are in comparison to the dangerous trades, they are nevertheless important and became increasingly so as the British economy shifted its focus away from manufacturing towards the service sector. 


\section{Tables and Figures}

Table 1: Gender and Average Age of Post Office workers granted a pension 1861-1891

\begin{tabular}{ccccc}
\hline & & \multicolumn{3}{c}{ Average Age } \\
Year & Male & Female & (years) & Total \\
\hline 1861 & 176 & 2 & 57.0 & 178 \\
1871 & 290 & 14 & 53.2 & 304 \\
1881 & 254 & 26 & 47.9 & 280 \\
1891 & 418 & 46 & 52.0 & 464 \\
\hline Total & 1138 & 88 & 52.1 & 1226 \\
\hline
\end{tabular}

Note to table 1: Four ages were not recorded

Source: POST 66 Staff Pensions and Superannuation (1713-1992), 1861, 1871, 1881, 1891

Table 2: Age of Post Office workers granted a pension 1861-1891

\begin{tabular}{cccccccc}
\hline & \multicolumn{2}{c}{$<45$ years } & \multicolumn{2}{c}{$45-59$ years } & \multicolumn{2}{c}{$60+$ years } & \\
& $\mathrm{N}$ & $\%$ & $\mathrm{~N}$ & $\%$ & $\mathrm{~N}$ & $\%$ & Total \\
\hline 1861 & 32 & 18.0 & 51 & 28.7 & 95 & 53.4 & 178 \\
1871 & 73 & 24.0 & 114 & 37.5 & 117 & 38.5 & 304 \\
1881 & 119 & 42.5 & 72 & 25.7 & 89 & 31.8 & 280 \\
1891 & 149 & 32.1 & 118 & 25.4 & 197 & 42.5 & 464 \\
\hline Total & 372 & 30.3 & 354 & 28.9 & 495 & 40.4 & 1226 \\
\hline
\end{tabular}

Note to table 2: Four ages were not recorded

Source: See Table 1 
Table 3: Reasons for retirement from the Post Office 1861-1891

\begin{tabular}{lccccccc}
\hline & \multicolumn{2}{c}{ III health } & \multicolumn{2}{c}{ Old Age } & \multicolumn{2}{c}{ Redundancy } & Total \\
& $\mathrm{N}$ & $\%$ & $\mathrm{~N}$ & $\%$ & $\mathrm{~N}$ & $\%$ & $\mathrm{~N}$ \\
\hline 1861 & 96 & 53.3 & 80 & 44.4 & 4 & 2.2 & 180 \\
1871 & 170 & 55.7 & 114 & 37.4 & 21 & 6.9 & 305 \\
1881 & 182 & 65.5 & 86 & 30.9 & 10 & 3.6 & 278 \\
1891 & 266 & 57.7 & 187 & 40.6 & 8 & 1.7 & 461 \\
\hline Total & 714 & 58.3 & 467 & 38.2 & 43 & 3.5 & 1224 \\
\hline
\end{tabular}

Note: Six cases had no identifiable reason for retirement.

Source: See Table 1 
Table 4: Average number of days off for ill health in ten years prior to retirement, 1861-1891

Average number of days off for ill health

in the last ten years

\begin{tabular}{lc}
\hline 1861 & 78.2 \\
1871 & 77.7 \\
1881 & 110.2 \\
1891 & 143.6 \\
\hline
\end{tabular}

Source: See Table 1

Table 5: Average number of days off for ill health in ten years prior to retirement 1861-1891

\begin{tabular}{cccc}
\hline & Male & Female & Average \\
\hline 1861 & 79.2 & N/A & 78.2 \\
1871 & 80.9 & 10.5 & 77.7 \\
1881 & 105.5 & 157.2 & 110.2 \\
1891 & 137.8 & 196.3 & 143.6 \\
\hline Average & 107.9 & 152.3 & 111.1 \\
\hline
\end{tabular}

Source: See Table 1 
Table 6: Cause of retirement for ill health using ICD 10 Classification of disease, 1861-1891

\begin{tabular}{|c|c|c|c|c|c|c|c|c|}
\hline ICD 10 & 1861 & $\begin{array}{l}1871 \\
\text { Numb }\end{array}$ & $\begin{array}{l}1881 \\
\text { er }\end{array}$ & 1891 & 1861 & 1871 & 1881 & 1891 \\
\hline \multicolumn{9}{|l|}{$\begin{array}{l}\text { Symptoms, signs, and abnormal } \\
\text { clinical and laboratory findings, }\end{array}$} \\
\hline $\begin{array}{l}\text { not elsewhere classified } \\
\text { Diseases of the musculoskeletal }\end{array}$ & 23 & 17 & 9 & 11 & 24.0 & 10.0 & 4.9 & 4.1 \\
\hline system and connective tissue & 18 & 36 & 46 & 41 & 18.8 & 21.2 & 25.3 & 15.4 \\
\hline \multicolumn{9}{|l|}{ Diseases of the eye and adnexa } \\
\hline (ear and mastoid process) & 12 & 20 & 20 & 12 & 12.5 & 11.8 & 11.0 & 4.5 \\
\hline Infectious and parasitic diseases & 11 & 16 & 23 & 48 & 11.5 & 9.4 & 12.6 & 18.0 \\
\hline Diseases of the circulatory system & 7 & 17 & 20 & 26 & 7.3 & 10.0 & 11.0 & 9.7 \\
\hline Mental and behavioural disorders & 6 & 23 & 15 & 43 & 6.3 & 13.5 & 8.2 & 16.1 \\
\hline Diseases of the nervous system & 6 & 12 & 7 & 16 & 6.3 & 7.1 & 3.8 & 6.0 \\
\hline Diseases of the respiratory system & 5 & 20 & 24 & 35 & 5.2 & 11.8 & 13.2 & 13.1 \\
\hline Diseases of the digestive system & 4 & 4 & 5 & 13 & 4.2 & 2.4 & 2.7 & 4.9 \\
\hline
\end{tabular}


Injury, poisoning, and certain

other consequences of external

causes

4

$\begin{array}{llllll}5 & 9 & 4.2 & 0.0 & 2.7 & 3.4 \\ 2 & 6 & 0.0 & 0.0 & 1.1 & 2.2 \\ 1 & & 0.0 & 0.0 & 0.5 & 0.0\end{array}$

metabolic disease

Diseases of skin and subcutaneous

tissue

2

$0.0 \quad 1.2$

$0.0 \quad 0.4$

Diseases of the genitourinary

system

Others/Unknown

$\begin{array}{lllllll}1 & 3 & 4 & 0.0 & 0.6 & 1.6 & 1.5\end{array}$

$\begin{array}{lllllll}2 & 2 & 2 & 0.0 & 1.2 & 1.1 & 0.7\end{array}$

\begin{tabular}{lllllllll}
\hline Total & 96 & 170 & 182 & 267 & 100.0 & 100.0 & 100.0 & 100.0
\end{tabular}

Source: See Table 1 


\section{Days off for}

illness in

previous 10 Average years Average Age

\begin{tabular}{lcccccccccc} 
& \multicolumn{3}{c}{ Gender (N) } & \multicolumn{2}{c}{ years } & \multicolumn{2}{c}{ of service } & \multicolumn{2}{c}{ (years) } \\
& Number & $\mathrm{M}$ & $\mathrm{F}$ & $\mathrm{M}$ & $\mathrm{F}$ & $\mathrm{M}$ & $\mathrm{F}$ & $\mathrm{M}$ & $\mathrm{F}$ \\
& & & & & & & & & \\
\hline London & 432 & 395 & 37 & 152.3 & 223.5 & 23.8 & 12.9 & 48.6 & 33.1 \\
Urban (100,000+) & 210 & 193 & 17 & 139.8 & 241.8 & 24.3 & 14.2 & 47.7 & 34.6 \\
Town (10,000-99,999) & 186 & 174 & 12 & 84.1 & 27.8 & 26.2 & 28.7 & 56.1 & 56.7 \\
Rural (Below 10,000) & 387 & 367 & 20 & 52.2 & 23.7 & 21.8 & 29.8 & 62.5 & 64.1 \\
\hline TOTAL & 1215 & 1129 & 86 & 107.9 & 152.3 & 23.6 & 19.3 & 52.7 & 43.9
\end{tabular}

Source: See Table 1

Note: Excludes postal workers not in the United Kingdom

Table 8: Average number of days off for ill health in ten years prior to retirement, 1861-1891

\begin{tabular}{lccc}
\hline & \multicolumn{3}{c}{ Age group (years) } \\
& $<45$ & $45-59$ & $60+$ \\
\hline London & 192.7 & 154.1 & 104.5 \\
Urban & 184.6 & 195.6 & 72.7 \\
Town & 135.6 & 131.9 & 31.7 \\
Rural & 112.0 & 61.3 & 29.6 \\
\hline
\end{tabular}

Source: See Table1 
Table 9: Letter carriers and rural messengers: days off for ill health in ten years prior to retirement, 1861-1891

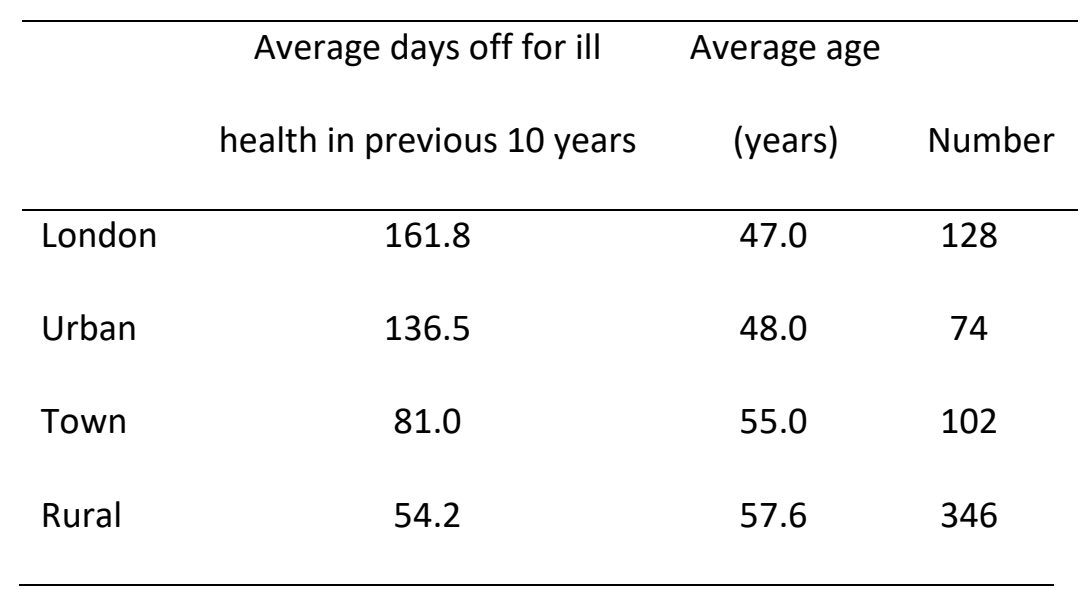

Note: Occupations include: London, Urban and Town (Letter carrier, postman, messenger, mounted messenger); Rural: (Rural messenger, rural post messenger, messenger, mounted messenger, railway messenger, station messenger, letter carrier, postman, postwoman).

Source: See Table 1 
Table 10: Disease classification by place, 1861-1891 (\%)

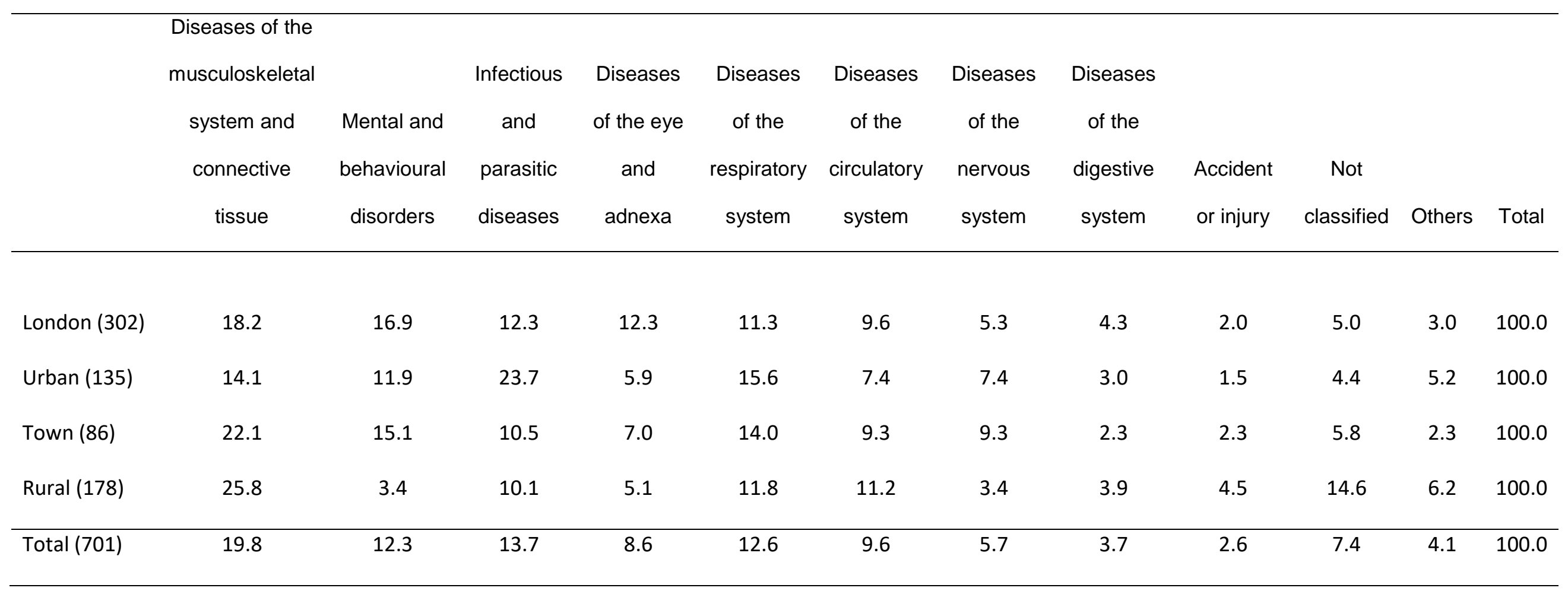

Source: See Table 1 
Figure 1: Cause of retirement in the Civil Service (10 years ending 30 November 1901)

Cause of retirement in the Civil Service (10 years ending 30

November 1901)

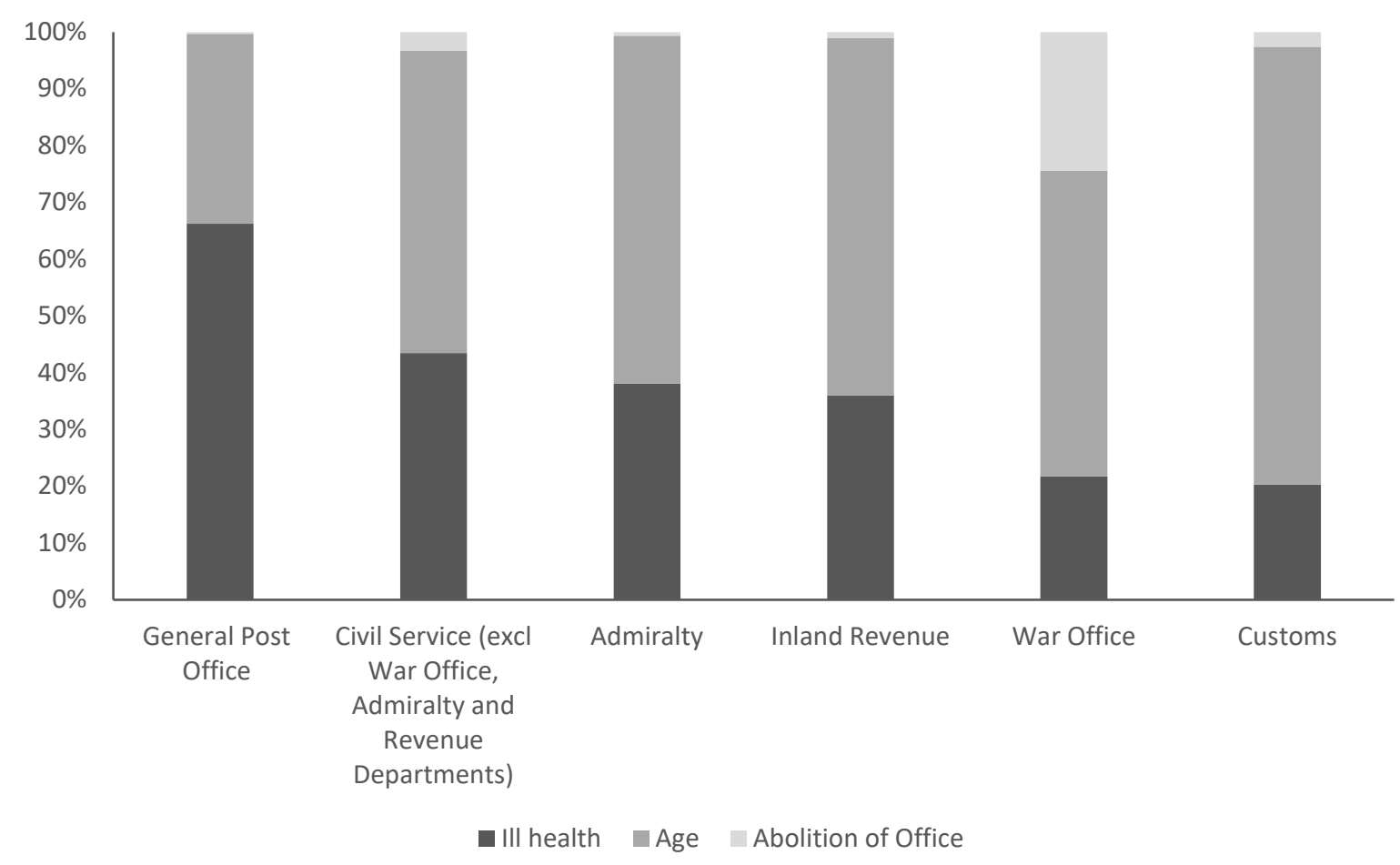

Source: 1903 [Cd. 1744] Report of the Commission on Superannuation in the Civil Service, Appendix 3, Return showing number of Civil Servants who have retired with pensions on account of age, ill health, abolition of office in the 10 years ended 30 November 1901, 192. 
Figure 2: The Central Telegraph Office, Instrument Room, London 1874

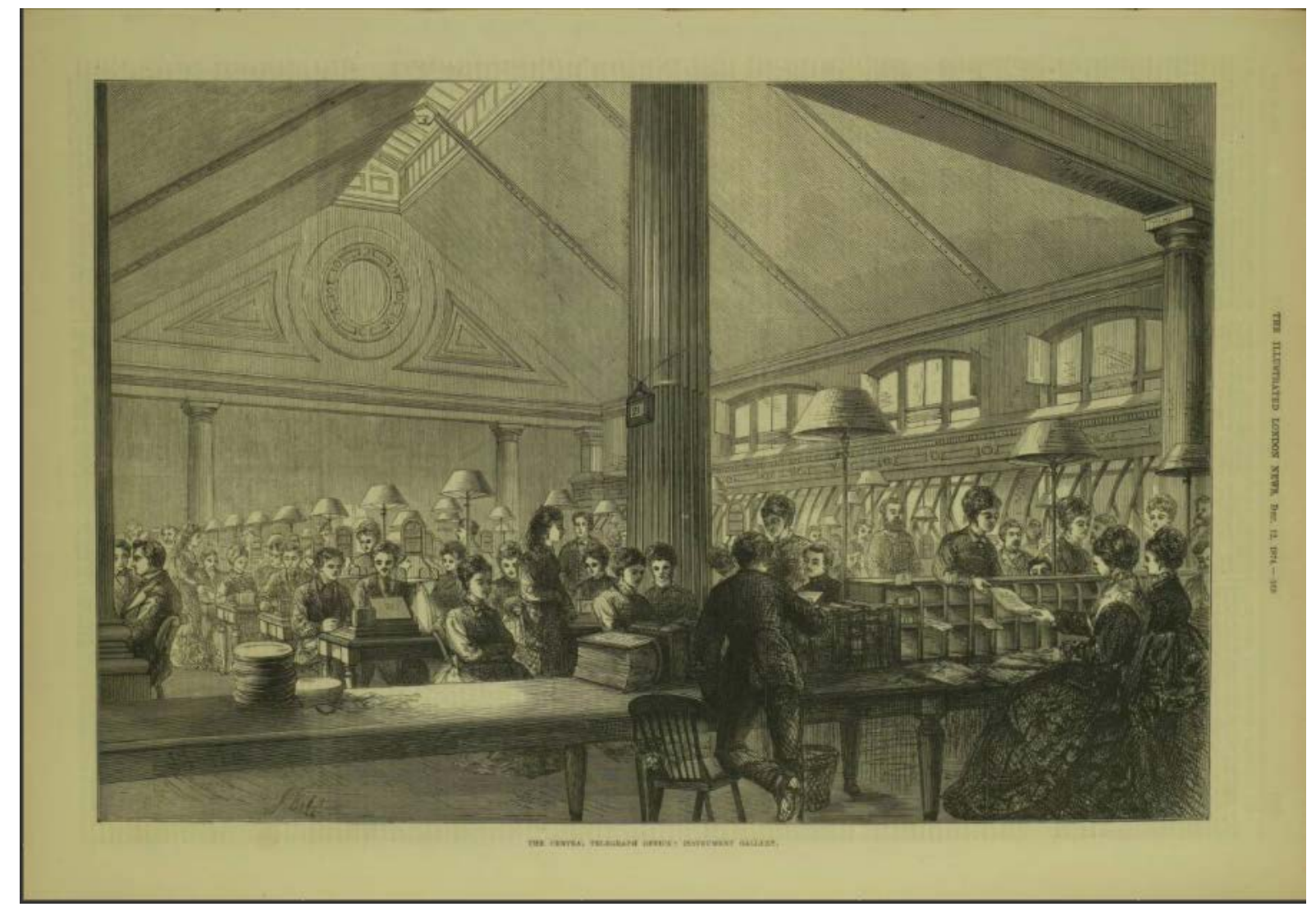

Source: Illustrated London News, 12 December 1874 
Figure 3: New uniforms for the Post Office, 1860

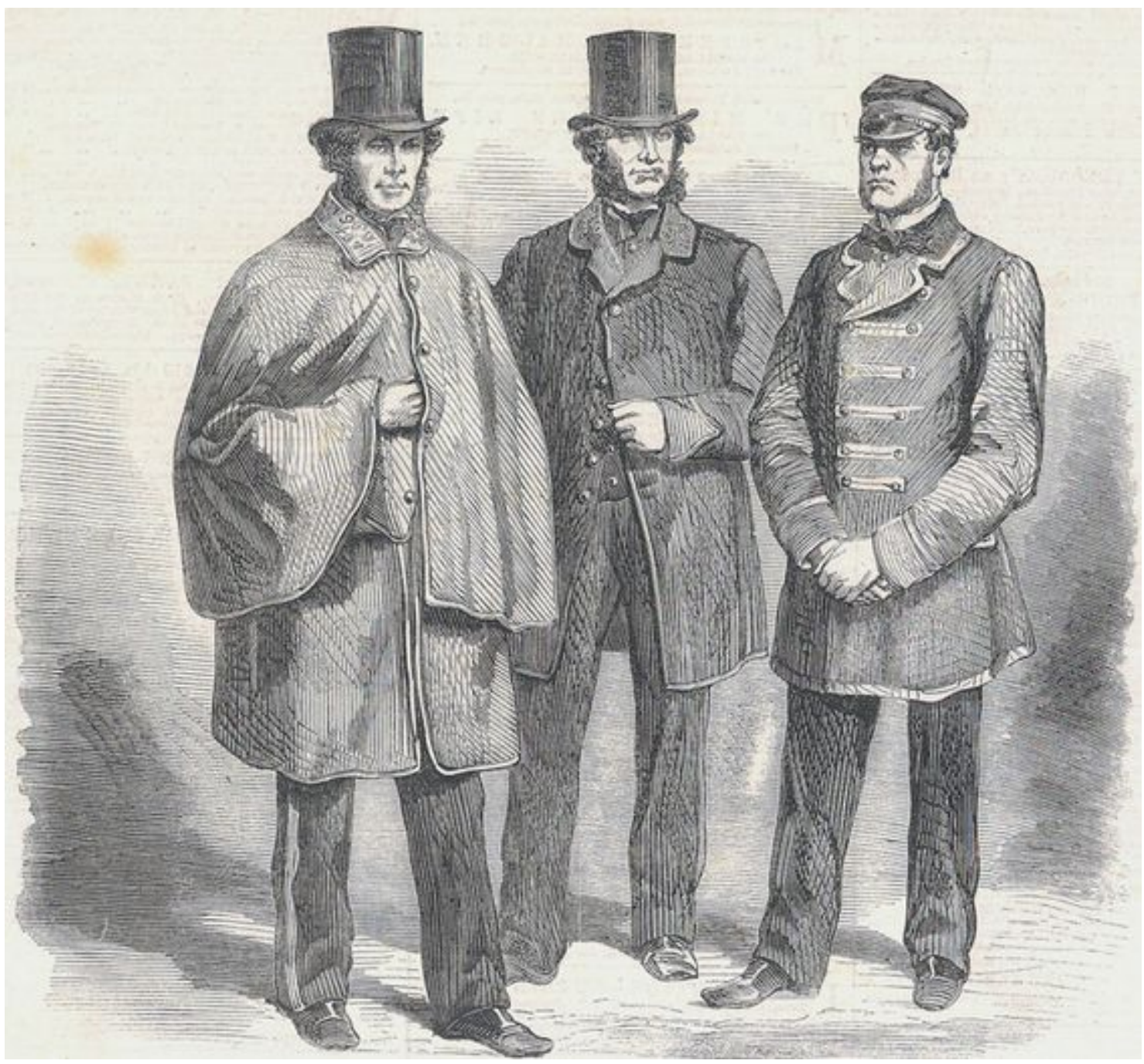

Note: the Inverness Cape is shown on the left

Source: Illustrated London News, 29 December 1860 
Figure 4: Reasons for being granted a pension by place of work, 1861-1891 (\%)

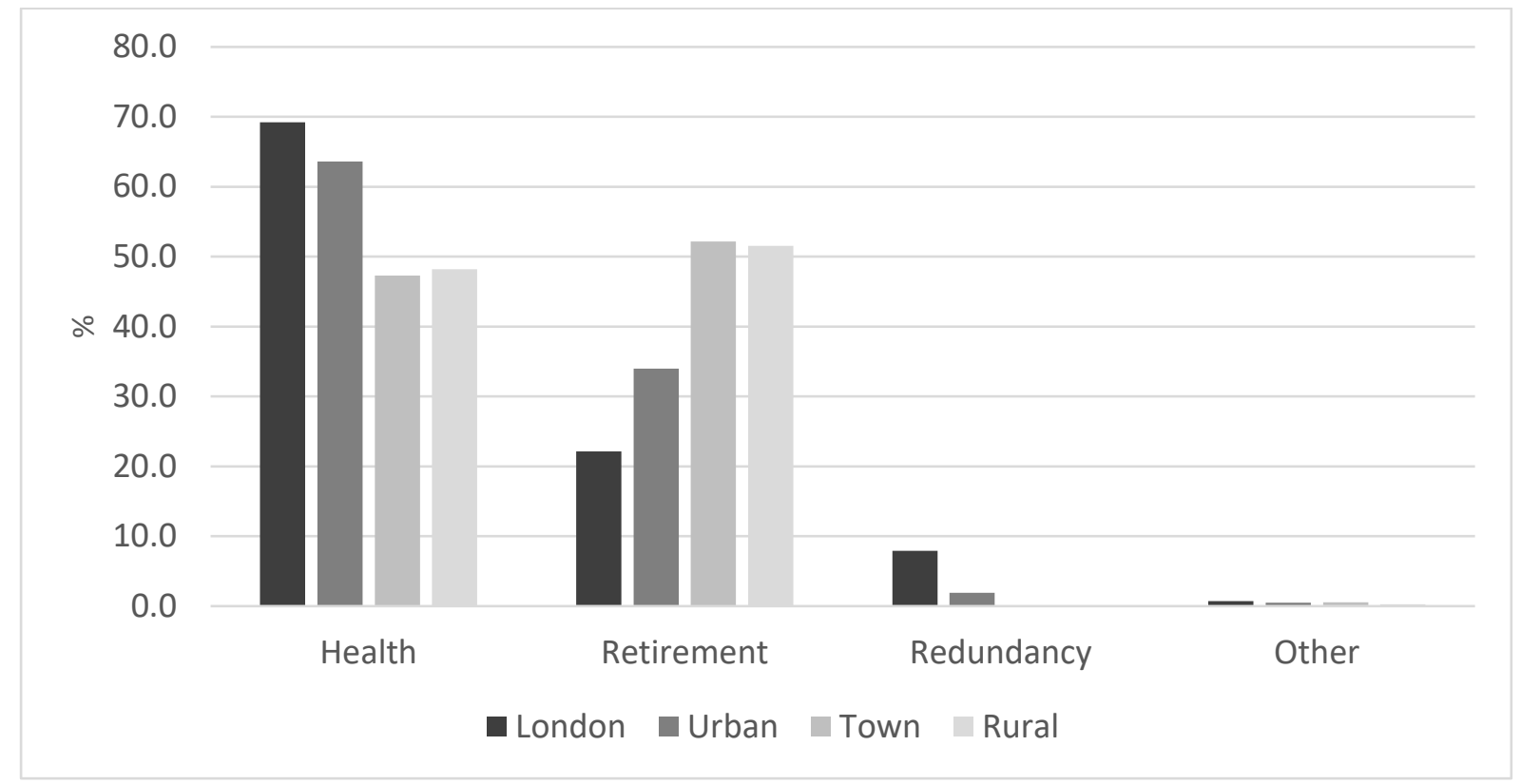

Source: See table 1 
Figure 5: The Six pm rush to catch the last post in London

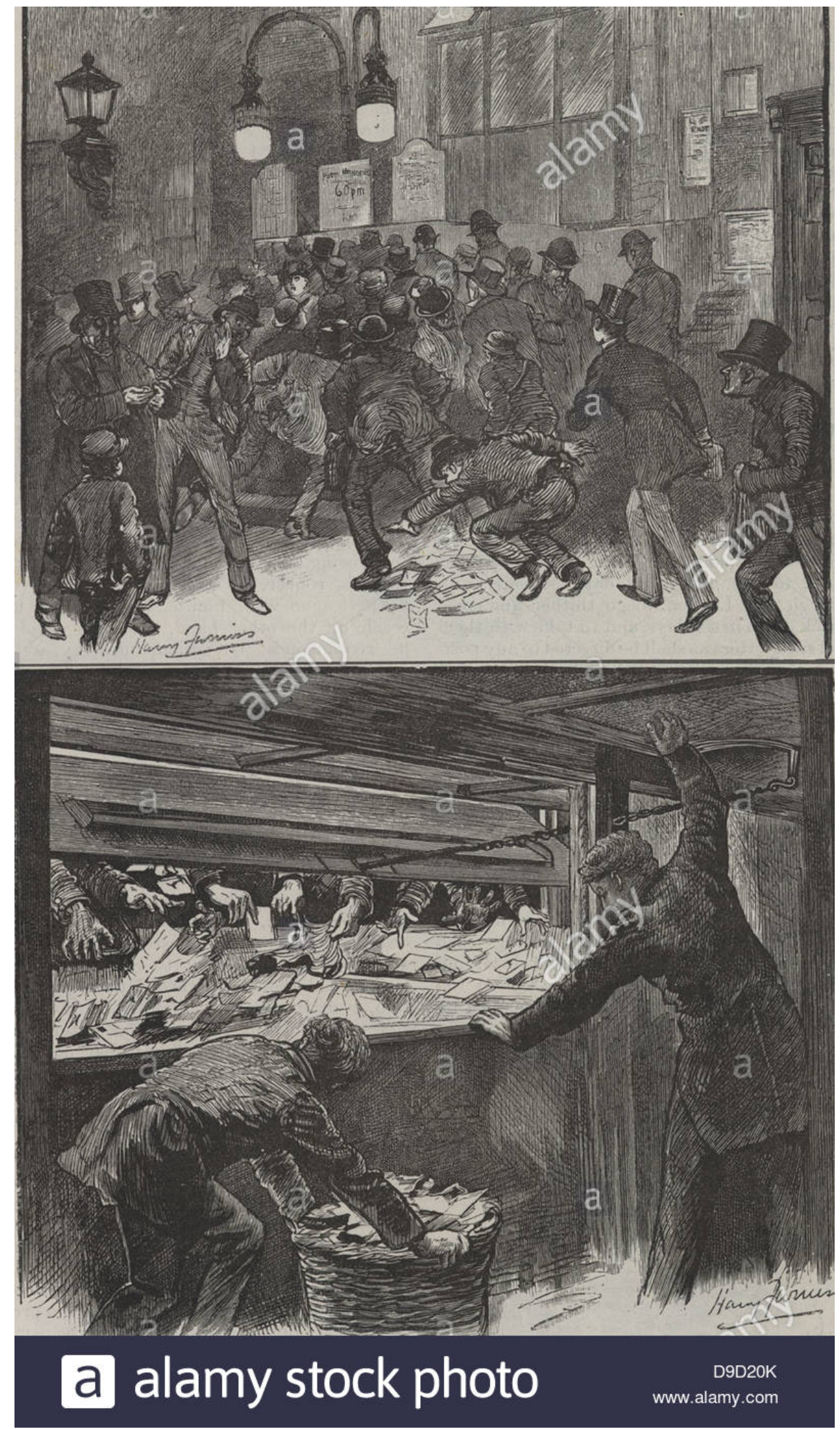


Source: Alamy (permission to be requested); Scene outside the General Post Office, St Martins-le-Grand, London, as people rush to catch the $6 \mathrm{pm}$ post for country letters. Bottom: The view from inside the post office. Illustration by Harry Furniss, 1884 